\title{
Building Quality of Democracy and Democratization of Political Party's Leader Election
}

\section{Sulardi Sulardi}

Faculty of Law, Universitas Muhammadiyah Malang, Indonesia. E-mail: sulardi.mgl@gmail.com

\begin{tabular}{l} 
ARTICLE INFO \\
\hline Keywords: \\
democratization; leader; \\
political party \\
How to cite: \\
Sulardi. (2020). Building \\
Quality of Democracy and \\
Democratization of \\
Political Party's Leader \\
Election. JURNAL \\
MEDIA HUKUM, 27(1), \\
33-43. \\
Article History: \\
Received: 08-08-2019 \\
Reviewed: 08-11-2019 \\
Revised: 21-02-2020 \\
Accepted: 24-06-2020
\end{tabular}

\begin{abstract}
Political parties are crucial assets of democracy. Political parties have strategic functions and roles in building democracy of a country. To create democracy and democratization, thus, the first subject who must practice democratization should be the political parties themselves. Until today, Indonesia is still in the process of seeking and progressing towards the ideal form of democratic living (democratization), as envisioned in the constitution. Surely, "the process of democratization" must be done in all aspects. Democratization in political parties has not been built well, as there are still some political parties whose election of leaders are still influenced by the parties' founder and family ties. Building quality of democracy may be initiated by the democratization of political parties, in this case through making better the election mechanism of the leader of the political party. This election process may be done democratically if: there are regulations which have been prepared from the beginning which guarantees the democratic changing process of the political party's leader. There should be no "familial" characteristics in the political parties which will actually create political party dynasties. There should also be a clear limitations regarding the head of the political parties' term of office and a more transparent and accountable election of political party's election of leader.
\end{abstract}

DOI: 10.18196/jmh.20200140

Copyright (C) 2020 MEDIA HUKUM. All rights reserved.

\section{Introduction}

In a democratic country, political parties are necessary organs. In a time where democracy is not known (anymore), there is no room for the life of political parties. With the development of the global politics and the striving for the citizens' rights in undergoing democracy, thus political parties exist. The status and the roles of political parties are crucial in every democratic system. Parties play a strategic role in becoming an ambassador between the government and the citizens. Moreover, many people have the opinion that the political parties are actually the determiner of democracy, as stated by Schattschneider (1942), "Political parties created democracy". Because of that, political parties have crucial roles whose degree of institutionalization must be strengthened in 
all democratic political systems. Even, Schattscheider also said that, "Modern democracy is unthinkable save in terms of the parties".

There are some functions of political parties. Miriam Budiardjo explained that there are at least four functions of political parties, in which one is related to the rest. These functions are: ${ }^{1}$ First, as an instrument of political communication. In this case, the political party's role is as an aggregator and an articulator of interests. As an aggregator of interests, they channel the various opinions and aspirations of the people, and manage them in a certain way, so as to minimize the confusion of the people's mixed opinions. Then, the opinions, ideas, policies, or aspirations of policies are managed and summarized so it is hoped that they may influence or become the material of the official stately policies. In conclusion, these two definitions state that political communication is a process of channeling and managing people's aspirations. ${ }^{2}$

Second, as a political socialization. Ideas, visions and strategical policies which become the choices of the political parties are socialized to the constituent to receive feedbacks in the form of the people's support. Regarding this political socialization, the parties also have a crucial role for political education. Parties become the intermediate structure which must play its role in realizing the state visions in the collective awareness of the citizens.

Third, as an instrument of political recruitment. This is a crucial function for the continuity and the existence of the political parties themselves. It is also to create a more qualified nation's leaders and the people's representatives. Basically, the parties are formed to become a valid "vehicle" in selecting the nation's prospecting leaders in certain positions. In this case, Umar states that the selection process is basically a systematic effort which is done to guarantee that those who are accepted are those who are considered to be the most proper, both are based on the determined criteria or based on the amount needed. ${ }^{3}$

Fourth, as a manager of conflicts, values, and interests which grow in the life of the people, which are various, complicated, and which have competitive tendencies, thus may form conflict between one and another. If there are many political parties, the various interests may be channeled through the polarization of the political parties which offer different ideologies, programs, and alternative policies from one another. This means that as conflict managers, parties have a function as an aggregator of interests which channel the different interests through the channel of the political party institution.

These four functions of the political party show that political parties are essential elements in building a democratic life. Until now, Indonesia is still in the process of finding the ideal form, for the sake of reaching an ideal democratic life (democratization) as envisioned in the Constitution. Certainly, the "process towards democracy" itself must be done in all aspects, including internal democratization within the political parties.

\footnotetext{
Budiardjo, M. (2000). Pengantar Ilmu Politik. Gramedia, p. 180.

Ibid, p. 171.

Umar, H. (2005). Riset Sumber Daya Manusia dalam Organisasi Edisi Revisi dan Perluasan. PT Gramedia Pustaka Utama, p. 90.
} 


\section{Method}

Doctrinal research is concerned with the formulation of legal 'doctrines' through the analysis of legal rules. Within the common law jurisdictions legal rules are to be found within statutes and cases (the sources of law) but it is important to appreciate that they cannot, in themselves, provide a complete statement of the law in any given situation. This can only be ascertained by applying the relevant legal rules to the particular facts of the situation under consideration. As will be discussed below in the section on methodology, deciding on which rules to apply in a particular situation is made easier by the existence of legal doctrines (e.g., the doctrine of consideration within the law of contract). These are systematic formulations of the law in particular contexts.

They clarify ambiguities within rules, place them in a logical and coherent structure and describe their relationship to other rules. The methods of doctrinal research are characterized by the study of legal texts and doctrinal research is therefore concerned with the discovery and development of legal doctrines for publication in textbooks or journal articles and its research questions take the form of asking 'what is the law ${ }^{4}$ ' in particular contexts. At an epistemological level this differs from the questions asked by empirical investigators in most other areas of built environment research.

This is perhaps most obvious in a comparison with research in the natural sciences which typically seeks to explain natural phenomena through studying the causal relationships between variables. Epistemologically, this is clearly very different from the interpretive, qualitative analysis required by doctrinal research. Although the interpretive nature of the process bears a superficial resemblance to the verstehen tradition of the social sciences ${ }^{5}$, there are actually fundamental epistemological differences between doctrinal analysis and all styles of scientific research. Scientific research, in both the natural and social sciences, relies on the collection of empirical data, either as a basis for its theories, or as a means of testing them. In either case, therefore, the validity of the research findings is determined by a process of empirical investigation. In contrast, the validity of doctrinal research findings is unaffected by the empirical world. Legal rules are normative in character as they dictate how individuals ought to behave ${ }^{6}$. They make no attempt either to explain, predict, or even to understand human behavior. Their sole function is to prescribe it. In short, doctrinal research is not therefore research about law at all. In asking 'what is the law ${ }^{7}$ ?, it takes an internal, participant- orientated epistemological approach to its object of study and, for this reason, is sometimes described as research in law ${ }^{8}$. As will be described below, the actual process of analysis by which doctrines are formulated owes more to the subjective, argument-based methodologies of the humanities than to the more detached data-based analysis of the natural and social sciences. The normative character of the law also means that the validity of doctrinal research must inevitably

${ }^{4}$ Melfa, W. (2013). Menggagas Amandemen UUD 1945 Dari Pemilukada. Jurnal Dinamika Hukum, 13(1), p. 441.

5 Schwandt, T. A. (2000). Three epistemological stances for qualitative inquiry: Interpretivism, hermeneutics and social constructionism. In N. K. Denzin \& Y. S. Lincoln (Eds.), Qualitative Research (2nd ed.). Sage Publications, p. 189.

${ }^{6}$ Hans Kelsen. (1967). In Knight, M. (trans) The Pure Theory of Law. University of California Press, p. 111.

7 Hart. (1961). The Concept of Law. Clarendon Press, p. 212.

8 Arthurs, H.W. (1983). Law and Learning: Report to the Social Sciences and Humanities Research Council of Canada by the Consultative Group on Research and Education in Law. Information Division Social Sciences and Humanities Research Council of Canada. Ottawa, p. 160. 
rest upon developing a consensus within the scholastic community, rather than on an appeal to any external reality.

\section{Analysis and Results}

\subsection{The Political Party Dynamics in Indonesia}

Generally, the development of political parties is parallel with the development of democracy. This applies in the broadening of the people's suffrage and the broadening of the parliament rights. ${ }^{9}$ Political parties were first born in the Western European countries. With the popularity of the opinion that the people are one of the factors which must be considered and which must be involved in the political process, thus political parties were born spontaneously. They then develop into the connector between the people on one side and the government on the other side. ${ }^{10}$

The political parties in Indonesia have a long history. Its existence may be traced to the invasion of the Dutch. At that time, there were the development of political powers on the grouping stage which is followed by polarization, expansion, and institutionalization. The Indonesian political party was born at the same time as the growth of the nationalist movements, which marked the era of the national awakening. Various modern organizations were created to contain the national movements which were formed for the sake of reaching the independence. Even though those organizations did not explicitly call themselves as political parties, yet they had political programs and activities. ${ }^{11}$

Budi Utomo (founded on May 20th, 1908) and Sarekat Islam (founded on 1911) are examples of organizations which do not explicitly state that they are political organizations. Yet in the development of those two organizations, their programs and activities have drifted into the political field. The existence of those two political organizations were followed with the findings of various political parties, such as Indische Partij (IP), Insulinde, Indische Sociaal Democratische Vereeniging (ISDV), Indonesians Communist Party (PKI), Indonesia National Party (PNI), Great Indonesia Party (Parindra), Party of Indonesia (Partindo), Indische Sociaal Democratische Partij (ISDP), Indische Katholijke Partij, Indonesians Movement Party (Gerindo), and Indonesia People Party (PRI).

The life of the Indonesian political parties before independence declined after 1930 . This happened because of the Dutch Colonial Government's application of repressive policies. General Governor B.C. de Jonge (1931) and A.W.L. Tjarda van Starkenborg Stachouwer (1936) refused to acknowledge these nationalist movement organizations. At that time, there were many political parties which were dissolved as they were believed to endanger the safety, the order, and the stability of the Dutch government. Between the parties which existed during the Dutch colonial government's time of power, those who were dissolved were IP, PKI, and PNI. ${ }^{12}$

9 Amal, I. (2012). Teori - Teori Mutakhir Partai Politik. Tiara Wacana, p.150.

$10 \quad$ Ibid p. 179.

11 Safa'at, M. (2006). Pembubaran Partai Politik Di Indonesia (Analisis Pengaturan Hukum dan Praktik Pembubaran Partai Politik 1959 - 2004). Dissertation. Fakultas Hukum Program Pascasarjana Universitas Indonesia. p. 212.

12 Nasution, A. B. (1995). Aspirasi Pemerintahan Konstitusional di Indonesia: Studi Sosio-Legal atas Konstituante 1956 - 1959. Pustaka Utama Grafiti, p. 300. 
The decline of the political activities during the Dutch colonial government's power continued until the colonialization of the Japanese. The Japanese colonial government strictly forbade all political activities, including meetings which talked about the governmental organization and structure. Even so, some figures of the political parties still had huge roles in their efforts to reach independence. Moreover, when BPUPKI (Badan Penyelidik Usaha-Usaha Persiapan Kemerdekaan/The Investigative Agency for Efforts to Prepare for Independence) and PPKI (Panitia Persiapan Kemerdekaan Indonesia/The Preparation Committee for the Indonesian Independence) were formed by the Japanese government, in which their memberships were filled with national figures who were leaders of the political parties.

Post-independence of Indonesia, President Soekarno at first wished for the existence of a single party to execute development, which he stated as "the motor of the people's struggle". In his speech as quoted in Merdeka, on August 25 th , 1945, President Soekarno wished that the party was Partai Nasional Indonesia. Yet, with the massive formation of KNIP (Komite Nasional Indonesia Pusat/The Indonesian Central National Committee) in different areas, thus the formation of PNI was postponed for some time. ${ }^{13}$ Until at last, the national figures realized the importance of political parties in a state. Thus, based on the advice from Badan Pekerja Komite Nasional Indonesia Pusat (BPKNIP/The Workforce Body of the Indonesian Central National Committee), the Governmental Edict (Maklumat) was issued on November 3rd, 1945, which states that the government supports the existence of political parties. It is said also that the political parties are hoped expected to already be formed before the election of the legislation members which are scheduled to be established on January 1946.

After that Governmental Edict, around 40 political parties were formed. ${ }^{14}$ Some political parties which have existed since the National Movement era grew with a new package. Those political parties had their own mass and basis of support.

On the time of the Presidential Decree application on July $5^{\text {th }}, 1959$, the Indonesian political party system experienced a simplification with the Presidential Decree No. 7 year 1959 and the Presidential Decree No. 13 year 1960 which regulates the acknowledgement, the supervision and the dissolution of political parties. Then, on April 14th, 1961 , there announced the 10 parties which received acknowledgement from the Indonesian government. Those 10 parties were PNI, NU, PKI, Partai Katolik, Partai Indonesia, Partai Murba, PSII, dan IPKI. Apart from that, the Presidential Decree No. 129 year 1961 regarding the Rejection of the Parties which was mentioned in the Presidential Decree No. 13 year 1960. The parties whose acknowledgements were rejected were PSII Abikusno, Public National Part Bebasa Daeng Lalo, and National People's Party Djodi Gondokusumo. Apart from that, through the Presidential Decree No. 440 year 1961 the parties which were acknowledged were Indonesians Christian Party (Parkindo) and Unified Islamic Tarbiyah (Perti). ${ }^{15}$ Meanwhile, Masjumi and PSI were dissolved the year before, through the issuing of the Presidential Decree No. 200/1960 on August 17th, 1960.

13 Budiardjo, M. (2008). Dasar-dasar Ilmu Politik. Gramedia Pustaka Utama, p. 231.

14 Asshiddiqie, J. (2005). Kemerdekaan Berserikat, Pembubaran Partai Politik, dan Mahkamah Konstitusi. Konstitusi Press, p. 172.

15 Karim, M. (1993). Perjalanan Partai Politik di Indonesia; Sebuah Potret Pasang-Surut. Rajawali Press, p. 161. 
The political dynamics in the Orde Baru (New Era) was marked with the dissolution of PKI (Partai Komunis Indonesia/The Indonesian Communist Party) on March 12th, 1966. Then, on February 20 2 th 1968 there was a step to melt down and to combine the Islamic society organizations which have existed, yet has not had their aspirations heard. Thus, Partai Muslimin Indonesia (PARMUSI) was established for that cause. Then, on March $9^{\text {th }}, 1970$, there was a grouping of parties, with the formation of Group of Development Democracy which consisted of PNI, Katholik Party, Parkindo, IPKI and Murba. After that, on March 13th, 1970, a group named United Development Party was established, consisting of NU, PARMUSI, PSII, and Perti. Lastly, there was a functional group which was grouped into one, and it is called Golongan Karya/Golkar or Group of Creations.

After the development of those political parties, then President Soeharto downsized the political parties which represented the people's aspirations at that time. Thus, on the 1977 election, there were 3 contestants, which are United Development Party (PPP), Indonesia Democracy Party (PDI) and one Golongan Karya. Up to the 1977 election, at this time, the participants of the election were the same as mentioned above, which are 2 political parties and one Group of Creations. During the new era/Orde Baru, Group of Creations always won the election.

After the political reform in 1998, there was a political euphoria. One of the indicators is the increasing numbers of political parties. The reformation era gave birth to a multiparty system as a primary point of the growth of parties which are based on the same political interests and orientation as their members. On 1999, the number of parties which participated in the election was 48 parties. On the 2004 election there were 24, and on 2009 there were 40 parties. This indicates the fertility of democracy in Indonesia, without the consideration of whether or not these parties have reached their goals.

\subsection{Development of the Democratization Quality}

Democracy is a form of a political government in which its power comes from the people, both directly (direct democracy) or through the representatives (representative democracy). This term came from the Greek word demokratia which means the people's power, which is formed from the words kata demos (people) and kratos (power). This refers to the political system which existed in mid-5th and in mid- $4^{\text {th }}$ century BC in Ancient Greece cities, especially Athena. ${ }^{16}$ Among the different definitions of democracy, perhaps the definition mentioned by Abraham Lincoln may summarize the meaning of democracy in a simple sentence. According to Abraham Lincoln, democracy is a government which comes from the people, by the people, and for the people.

Democracy emphasizes the willingness, the opinions, and the views of the people. The model of democracy is chosen through an agreement of a consensus. Thus, a strong democracy is a democracy which comes from the heart of the people to reach the justice and the welfare of the people. ${ }^{17}$ Just like a system, democracy also has its own concepts, characteristics, models, and mechanisms. All of them are one unity which may explain the meaning, the aim and the practice of the democratic system.

\footnotetext{
16 Azra, A. (2005). Demokrasi, Hak Asasi Manusia, dan Masyarakat Madani. Prenada Media, p. 115.

17 Bangun, Z. (2008). Demokrasi dan Kehidupan Demokrasi di Indonesia. Bina Media Perintis, p. 220.
} 
As an ideal system, democracy is surely hoped for by many people. Yet, the effort towards the ideal democracy is not an easy process. This process is called democratization. Political democratization may mean a transition; a process towards a more democratic "political regime".

The democratization of the politics in Indonesia has developed step by step. As a comparison, as mentioned before regarding the New Era, the freedom of undergoing politics was very limited and full of intervention. The parties which may compete in the election were limited to three parties, which are:

1. PPP (United Development Party) which is based on Islamic ideologies, which is the fusion of NU parties, Parmusi, PSII, and Partai Islam.

2. Group of Creations which is based on the principle of creation and social justice.

3. PDI (Indonesia Democracy Party) which is based on democracy, nationalism, and justice. It is a fusion of Parkindo, Katolik Party, PNI, and Murba.

In fact, there was only one party which held power, which was the Golkar party under the reign of President Soeharto. For years, the Golkar party stood strong as the vehicle of President Soeharto to have power. During those years, the freedom of the people especially in undergoing politics - were limited, as Soeharto viewed that the political parties were a source of disorder for the political system he built. This is not to mention the obligatory mono-loyalty of Civil Servants towards the Golkar party. Basically, the New Era party did not observe an effective participation of the people, and the power is under the reign of the government. Thus, it cannot be said that the government in the New Era was a fully democratic government.

Yet, this condition was inversely proportional in the reformation era. In the start beginning of the reformation, there were many pressures from various elements of the society, pushing for a more democratic political condition of Indonesia. Thus the tap of democracy was opened as wide as possible by President BJ. Habibie with the issuing of Law No. 2 of 1999 on Political Party. Because of that, new political parties emerged and participated in the general election year 1999 - where 48 out of the 141 political parties which registered themselves to the Department of Justice participated in the election. Then, on the 2004 election, 24 parties participated in the Election, followed by 40 parties in the 2009 election, and 10 parties in the 2014 election and democracy quality rises rather than in Soeharto era.

The existence of the freedom of people/groups to form political parties is an evidence that the political democratization in Indonesia is getting better. The formation of political parties is a real implementation of the freedom of forming or participating in groups and the freedom of speech. Then, as a result of the development of the healthy freedom to form groups, societal organizations and political parties exist which make the civilians even more mature and developed. In the context of Indonesia, it is hoped that the existence of political parties is supported by the freedom to form and to participate in groups, which refers to the values of Pancasila.

\subsection{Electing Leaders of Political Party}

Democracy is an ideal concept which is envisioned by the government. The efforts to reach an ideal democracy haven't been an easy process. To build a democratic political life, efforts should start from the roots which means that it should start internally from the political parties. The political parties' internal democracy is the process of electing the prospecting leaders of the party by absorbing the aspirations of all cadres in the 
grass root level, so that the elected leader is the aspiration of his/her cadres. ${ }^{18}$ Thus, the party's internal democracy process is a manner to attain a leader by applying a mechanism of collecting the votes of all cadres in the party, so that the elected leader of the party obtains the strong legitimacy to undergo his/her function as the highest leader in the party.

Next, Arbi Sanit (2003) in his book which is entitled, "Pembaharuan Mendasar Partai Politik" (The Basic Renewal of Political Parties) explained that there are two strategies in electing the leader of a political party:19 First, this process is a revision of the recruitment system in political parties, by emphasizing the cadre's party, training the cadres systematically and with direction to form democratic as well as effective leaders. Apart from that, the standard and the indicator of a cadre's development are usually related to the cadre's position in the structure of the party and in the state.

Second, this process poses a crucial meaning towards the changing of the recruitment system of the party's leader. By competing openly, the qualification of the leader will have more quality, and there will be the widest possible participation from the party's members and from the society. The manifestation may be by using a local and a national convention system, district or direct election system, personal and leadership qualification of the prospecting leaders, and the participation of the people.

The description above shows that the position as a political party's leader is a strategic position which may influence the democratization process in Indonesia. This is because a party's leader can determine the platform of the political party's policies, the political party's policies towards the government, also control the party's cadres who are in the government, whether they are in the legislative of in the executive positions. Thus, a leader with quality is a necessity. The possibility to obtain a leader with quality is strictly influenced by the party's internal democratic process.

Yet, seeing the status quo, the parties' internal democratic processes do not really occur democratically. The victory of a leader is strictly determined by his/her power, like his/her background of profession (military, entrepreneur, bureaucrat), his/her financial power, his/her descent or political dynasty. These powers are often used by the prospecting leaders to smoothen their way to be in the saddle of the political party. Apart from that, the cadres tend to emphasize the political pragmatism in electing a leader, like offers of money, position, and other incentives, thus eliminating the consideration of quality, morals, etc.

A method of analysis to see that condition is Gun Gun Heryanto's opinion which divides three traditions of Indonesia's political party tradition, namely: First, the feudal tradition. The feudal tradition of Indonesian political parties is marked by the political party's dependency towards a particular figure. The main reference to describe this phenomenon is the reelection of old elites in the leadership of political parties these past few years. One example is the election of PDIP (Indonesia Democracy Party of Struggle)'s leader. The election of this party' s leader, whose symbol is a bull, was done through the congress. Since 1999 until now, there have been 4 elections of PDIP's leader, and during that time also, Megawati (Soekarno heir apparent political dynasty) has been always the leader of this party. Moreover, in the current period, Megawati

18 Warre, A. (1996). Political Parties and Party Systems. Oxford University Press, p. 235.

19 Sanit, A. (2003). Pembaharuan Mendasar Partai Politik. In M. Irsyam \& L. Romli (Eds.), Menggugat Partai Politik. Laboratorium Ilmu Politik FISIP UI, p. 180. 
has been chosen in the National Work Meeting of PDIP in Semarang. This is because there is no other stock of prospecting leaders in the party apart from her. Thus, in the PDIP Congress IV event, there were no processes of election of a leader, yet there was a direct inauguration for Megawati to become the leader until 2020. Though the process of leader's election was done through the congress, yet factually, Megawati's power in that process is enormously strong, thus she was elected before the election. Yet, there are other PDIP cadres who are of quality as a regeneration to hold the power as PDIP's leaders, such as Pramono Anung, Sirait, and Tjahyo Kumolo.

One factor of why Megawati is so strong in that party, is that there is a stigma among the cadres that as a founder, PDIP is "owned" by Megawati, and that she is a figure who unifies the party. Apart from that, she is a descendent of Soekarno, therefore she has power that no one else has. Moreover, the Central Board General Secretary of PDIP, Tjahjo Kumolo stated that as long as parties live, PDIP cannot be separated from the descendants of the first president, Soekarno. ${ }^{20}$ Of course, this statement may "threats" the party's internal democracy process.

Second, the oligarchic tradition. In the oligarchic tradition, the leaders who will be placed in the public positions must ask for approval to the leader of their political parties. Third, the transactional tradition. If connected to the election of the party's leader, this tradition shows that financial power may determine the leader position (Oligarchic behavior). An example of this phenomenon is on the National Conference of Golkar Party on 2004. The results of the National Conference chose Jusuf Kalla as the leader of Golkar on 2004, succeeding Akbar Tandjung. This happens even though Akbar's achievements were great in defending Golkar in the era where the people pressured this party to be dissolved. He even struggled so that Golkar can reach victory in the Legislative Election on 2004. Akbar Tandjung was succeeded by Jusuf Kalla as at that time he had an access to the governmental position as Vice President. He also had financial power as a rich businessman.

Next, on the National Conference on 2009, Aburizal Bakrie was chosen as the leader. This is a continuation of the political pragmatism on the 2004 National Conference. As commonly known, at that time, Aburizal Bakrie held the position as the Minister of Economy and Social Welfare in SBY's first and second cabinet. This becomes one of his bargaining powers which makes the cadres choose him, as he has an access towards a strategic position in the Governmental Cabinet. Apart from that, Aburizal Bakrie has financial power as he is known to be the richest person in Southeast Asia, according to Globe magazine.

\subsection{Election a Democratic Leader of the Political Party}

If these traditions keep on being practiced, thus quality democracy will be hard to reach. As mentioned earlier, political parties are a crucial instrument in a democracy, yet factually it is the other way around. Political parties often fail to democratize themselves. Thus, there should be democratization inside the political parties through some programs as follows:

1. There should be political parties' internal regulation which is usually written in their Basic Budget and Operational Budget regarding the requirements of the leader

20 Rofiuddin. (2014, September 21). Ketua Umum PDIP Hanya untuk Trah Soekarno. https://m.tempo.co/read/news/2014/09/21/078608499/ketua-umum-pdip-hanya-untuk-trahsoekarno 
and the method of electing a leader. These regulations give a legal insurance towards the changing process of political parties.

2. It regulates the leader of the political party's limitation regarding the length of the service. Normally, someone has a tenure as leader of a political party for two terms of offices.

3. There are no blood-relations between the preceding leader and the successor, to avoid the problem of a political party's dynasty which will actually inhibit democratization in a political party.

4. It should be established openly, both through convention or election based on the existing requirements.

5. There should be accountability of the political party's leader which is more transparent and measurable and therefore people can see the successes and the failures of the political party's programs.

\section{Conclusion}

As democracy's crucial instrument, a democratic living must start from the internal of political parties, by democratizing them and fixing the recruitment. Political parties must have the courage to reconstruct the policy of the political party leader's election. The method of leader's election must be democratic and must represent the members' aspirations. There are some issues which must be fixed, like the elimination of the feudal, oligarchic, and transactional mechanisms. There should be an elective mechanism of the political party's leader which is more democratic, opened, and responsible. Thus, the quality of democratic life may be reflected from the grass-root level and leaders with quality will be born for the future.

\section{References}

Books:

Amal, I. (2012). Teori - Teori Mutakhir Partai Politik. Tiara Wacana.

Arthurs, H.W. (1983). Law and Learning: Report to the Social Sciences and Humanities Research Council of Canada by the Consultative Group on Research and Education in Law. Information Division Social Sciences and Humanities Research Council of Canada. Ottawa.

Asshiddiqie, J. (2005). Kemerdekaan Berserikat, Pembubaran Partai Politik, dan Mahkamah Konstitusi. Konstitusi Press.

Azra, A. (2005). Demokrasi, Hak Asasi Manusia, dan Masyarakat Madani. Prenada Media.

Bangun, Z. (2008). Demokrasi dan Kehidupan Demokrasi di Indonesia. Bina Media Perintis.

Budiardjo, M. (2000). Pengantar Ilmu Politik. Gramedia.

Budiardjo, M. (2008). Dasar-dasar Ilmu Politik. Gramedia Pustaka Utama.

Hart. (1961). The Concept of Law. Clarendon Press.

Karim, M. (1993). Perjalanan Partai Politik di Indonesia: Sebuah Potret Pasang-Surut. Rajawali Press. 
Kelsen, H. (1967). In Knight, M. (trans). The Pure Theory of Law. University of California Press.

Nasution, A. B. (1995). Aspirasi Pemerintahan Konstitusional di Indonesia: Studi Sosio-Legal atas Konstituante 1956 - 1959. Pustaka Utama Grafiti.

Sanit, A. (2003). Pembaharuan Mendasar Partai Politik. In M. Irsyam \& L. Romli (Eds.), Menggugat Partai Politik. Laboratorium Ilmu Politik FISIP UI.

Schwandt, T. A. (2000). Three epistemological stances for qualitative inquiry: Interpretivism, hermeneutics and social constructionism. In N. K. Denzin \& Y. S. Lincoln (Eds.), Qualitative Research (2nd ed.). Sage Publications.

Umar, H. (2005). Riset Sumber Daya Manusia dalam Organisasi Edisi Revisi dan Perluasan. PT Gramedia Pustaka Utama.

Warre, A. (1996). Political Parties and Party Systems. Oxford University Press.

\section{Journal articles:}

Melfa, W. (2013). Menggagas Amandemen UUD 1945 Dari Pemilukada. Jurnal Dinamika Hukum, 13(1), 171-178.

\section{Internet:}

Rofiuddin. (2014). Ketua Umum PDIP Hanya untuk Trah Soekarno. https://m.tempo.co/read/news/2014/09/21/078608499/ketua-umum-pdiphanya-untuk-trah-soekarno

\section{Dissertation:}

Safa'at, M. (2009). Pembubaran Partai Politik Di Indonesia (Analisis Pengaturan Hukum dan Praktik Pembubaran Partai Politik 1959 - 2004). Dissertation. Fakultas Hukum Program Pascasarjana Universitas Indonesia. 